\title{
Thyrotropin-releasing hormone gene expression in the human hypothalamus
}

\author{
Stephan E.F. Guldenaar ${ }^{\mathrm{a}, *}$, Bastiaan Veldkamp ${ }^{\mathrm{a}}$, Onno Bakker ${ }^{\mathrm{b}}$, Wilmar M. Wiersinga ${ }^{\mathrm{b}}$, \\ Dick F. Swaab ${ }^{\mathrm{a}}$, Eric Fliers ${ }^{\mathrm{b}}$ \\ ${ }^{a}$ Graduate School of Neurosciences Amsterdam, Netherlands Institute for Brain Research, Meibergdreef 33, 1105 AZ Amsterdam, The Netherlands \\ b Department of Endocrinology, Academic Medical Center of the University of Amsterdam, Meibergdreef 9, 1105 AZ Amsterdam, The Netherlands
}

Accepted 13 August 1996

\begin{abstract}
We studied the distribution of mRNA coding for thyrotropin-releasing hormone (TRH) in the human hypothalamus by means of in situ hybridization. In 10\% formalin-fixed paraffin-embedded tissue sections of five hypothalami, TRH mRNA-containing cells were found in several nuclei and areas. Numerous TRH mRNA-containing cells were detected in the medial region of the caudal part of the paraventricular nucleus. These neurons were heavily labeled and mainly small to medium-sized. Few, lightly- and medium-labeled, small cells were detected in the suprachiasmatic nucleus. In addition, heavily labeled single cells were found in the perifornical area and the anterior- and lateral hypothalamic regions. In the latter region, occasional heavily labeled cells were found just dorsal to the supraoptic nucleus. Neither in the supraoptic nucleus nor in the sexually dimorphic nucleus of the preoptic area were TRH mRNA-containing cells found. This is the first description of TRH mRNA containing cells in the human hypothalamus.
\end{abstract}

Keywords: Hybridization, in situ; Paraventricular nucleus; Perifornical area; Suprachiasmatic nucleus; Supraoptic nucleus; Thyroid; Human brain

\section{Introduction}

In rat brain, thyrotropin-releasing hormone (TRH) was identified in hypothalamic and extrahypothalamic areas by radioimmunoassay $[9,16,51]$ and immunocytochemistry $[15,22,23,26,32,46,47]$.

In man, the distribution of TRH in the hypothalamus was described by means of radioimmunoassay $[5,25,36]$ and, more recently, by immunocytochemistry [13]. In addition, extrahypothalamic TRH-immunoreactive (TRH-IR) fibers were demonstrated in the human spinal cord [17].

The neuroendocrine role of TRH as a modulator of thyroid-stimulating hormone (TSH) in the human anterior pituitary and, therefore, the importance of TRH in the human hypothalamus-pituitary-thyroid (HPT) axis was supported by the presence of TRH-IR cells in the human paraventricular nucleus $(\mathrm{PVN})$ and TRH fiber terminations

Abbreviations: AC, anterior commissure; DB, diagonal band of Broca; FO, fornix; III, third ventricle; NTL, lateral tuberal nucleus; OC, optic chiasm; OT, optic tract; PVN, paraventricular nucleus; SCN, suprachiasmatic nucleus; SDN-POA, sexually dimorphic nucleus of the preoptic area; SON, supraoptic nucleus; VM, ventromedial nucleus.

${ }^{*}$ Corresponding author. Fax: + 31 (20) 696-1006. around blood capillaries of the median eminence [13]. In addition, the finding of TRH-IR fibers and fiber terminations within the hypothalamus [13] was consistent with a role for TRH as a neurotransmitter or neuromodulator in human brain.

In rats, an inverse relationship between the level of circulating thyroid hormone and the level of TRH mRNA was found in medial parvicellular neurons of the PVN, but not in neurons in any other region of the hypothalamus $[12,24,27,40]$, confirming earlier immunocytochemical studies involving thyroid hormone-deficient rats [35].

Additional factors appeared to affect hypothalamic TRH gene expression in the rat. While a reduction of TRH gene expression in the PVN by glucocorticoids in vivo was shown [21], Luo et al. [29] demonstrated that glucocorticoids significantly enhanced TRH mRNA levels in cultured hypothalamic neurons. Moreover, Kakucska et al. [20] found that, in the rat, peripheral administration of endotoxin or central administration of interleukin- $1 \beta$ was associated with a proTRH mRNA content in the PVN that may be inappropriately normal or reduced for the level of circulating thyroid hormone. These findings appear to support the hypothesis that TRH gene expression of the PVN plays a role in the pathogenesis of nonthyroidal illness, i.e., the occurrence of low thyroid hormone levels 
and inappropriately low or normal TSH plasma levels in the setting of severe illness.

Selective feedback effects of thyroid hormone on hypothalamic TRH gene expression in man have not been reported in the literature. Indeed, the presence and location of cells containing mRNA coding for TRH in the human hypothalamus have not been demonstrated. Accordingly, we mapped TRH mRNA-expressing cells in the human hypothalamus by means of in situ hybridization.

\section{Materials and methods}

\subsection{Tissues}

Hypothalami of six male subjects who had died of various causes (Table 1) were dissected at brain autopsy. Whereas the hypothalamus of subject \#88035 was not divided, the remaining hypothalami were cut midsagittally; one half was used for the present study, the other for the immunocytochemical localization of TRH [13]. Hypothalamic tissues were fixed in $10 \%$ formalin at room temperature. Tissues were dehydrated in a graded ethanol series, cleared in xylene and embedded in paraffin.

Hypothalamic sections containing the PVN of subject \#88035 were used extensively in pilot experiments and specificity tests. Due to the limited number of sections remaining, the hypothalamus of subject \#88035 was not used for the mapping study. The hypothalamus of subjects \#93005 and \#93047 were used in pilot experiments and in the present study. Neuropathology was performed either by Dr. W. Kamphorst (Free University, Amsterdam) or Prof. F.C. Stam (Netherlands Brain Bank, Amsterdam).

\subsection{Histology}

Coronal sections ( $6 \mu \mathrm{m}$ thick) were made from the level of the lamina terminalis to the mammillary bodies.
Every 100th section was collected on chromealum-gelatine coated slides and stained with thionin for orientation and identification of anatomical landmarks, e.g., PVN and supraoptic nucleus (SON). The rostral part of the hypothalamus was sampled more frequently (sampling interval of 25 sections) to identify the small nuclei e.g. suprachiasmatic nucleus ( $\mathrm{SCN})$ and sexually dimorphic nucleus of the preoptic area (SDN-POA). The presence of the SCN was confirmed in all subjects by means of immunohistochemical staining for vasopressin [45], since this nucleus cannot be distinguished in $6 \mu \mathrm{m}$ sections by thionin staining. In general, we adopted the anatomical nomenclature and schemes from Braak and Braak [6]. Since the SDN-POA's original description [44] it has been named interstitial nucleus of the anterior hypothalamus-1 (INAH1) [1] or intermediate nucleus [6]. We adhere to the name SDN-POA to indicate the sexual dimorphism of this nucleus of the preoptic area.

\subsection{Probe preparation}

Two human TRH cRNA antisense probes were prepared. Restriction enzymes and polymerases were obtained from Boehringer Mannheim. For the first probe, after restriction with NdeI (base position 546) and blunting of the overhang at the NdeI site with Klenow DNA polymerase (to base position 549), a 219 base pair preproTRH cDNA fragment was excised with $B g l$ II (base position 330) from a longer human TRH cDNA characterized by Yamada et al. [53] (kindly provided by Dr. K.M. Gautvik, Inst. Medical Biochemistry, Univ. of Oslo). The 219 base pair fragment was purified from a gel by electroelution (HSB-Elutor E51, Biometra) and subcloned in pBluescript (Stratagene). For the second probe, we used the polymerase chain reaction (PCR) with the following primers: sense primer 5'-CA ACG AAT TCG GCT GCT GTG GGA CCC CAC A-3' and antisense primer $5^{\prime}-\mathrm{C}$ TTG TTC GAA GCT CCT TTG AGC CTT GG-3', to obtain a

Table 1

Brain material

\begin{tabular}{|c|c|c|c|c|c|c|c|}
\hline $\begin{array}{l}\text { Subject }(ठ) \\
\text { no. }\end{array}$ & $\begin{array}{l}\text { Age } \\
\text { (years) }\end{array}$ & $\begin{array}{l}\text { Clock time } \\
\text { of death }\end{array}$ & $\begin{array}{l}\text { Date of death } \\
(\mathrm{d} / \mathrm{m} / \mathrm{y})\end{array}$ & $\begin{array}{l}\text { Brain } \\
\text { weight }(g)\end{array}$ & $\begin{array}{l}\text { Postmortem } \\
\text { delay }(\mathrm{h})\end{array}$ & $\begin{array}{l}\text { Fixation } \\
\text { time (days) }\end{array}$ & $\begin{array}{l}\text { Clinical } \\
\text { diagnosis }\end{array}$ \\
\hline 88.035 & 23 & $\begin{array}{l}\text { not } \\
\text { determined }\end{array}$ & $10 / 04 / 88$ & 1540 & $<48$ & 28 & $\begin{array}{l}\text { Transmural myocardial infarction, } \\
\text { familial hypercholesterolemia }\end{array}$ \\
\hline 93.005 & 72 & 10.30 & $12 / 01 / 93$ & 1196 & 4.5 & 30 & $\begin{array}{l}\text { Acute heart failure, } \\
\text { long-standing cardiovascular disease, } \\
\text { carcinoma of the bladder }\end{array}$ \\
\hline 93.047 & 70 & 15.20 & $27 / 03 / 93$ & 1325 & 4.5 & 28 & $\begin{array}{l}\text { Alzheimer's disease, } \\
\text { urinary tract infection, } \\
\text { ileus, ischemic heart disease }\end{array}$ \\
\hline 93.049 & 84 & 04.15 & $29 / 03 / 93$ & 1429 & 4.0 & 31 & $\begin{array}{l}\text { Dementia with extrapyramidal disorder, } \\
\text { chronic obstructive pulmonary disease }\end{array}$ \\
\hline 93.103 & 83 & 05.00 & $27 / 08 / 93$ & 1210 & 8.0 & 31 & Malignant tumor of right lung \\
\hline 93.112 & 67 & 03.40 & $17 / 09 / 93$ & 1275 & 9.0 & 34 & $\begin{array}{l}\text { Myocardial infarction, } \\
\text { pneumonia and mediastinitis }\end{array}$ \\
\hline
\end{tabular}


182-base pair fragment located between base 430 and base 611 of the TRH cDNA [53]. This PCR fragment was also purified from a gel by electroelution and subcloned in pBluescript.

Templates for anti-sense human TRH cRNA probe synthesis were prepared by linearizing the respective plasmids with $X b a I$ or EcoRI. Subsequently, the templates were transcribed with T7 RNA polymerase in the presence of $\left[{ }^{35} \mathrm{~S}\right] \mathrm{CTP}$ (Amersham). The specific activity of the probes was $\sim 1.5 \times 10^{9} \mathrm{dpm} / \mu \mathrm{g}$.

Identical results were obtained with both antisense TRH cRNA probes in pilot experiments with hypothalamic sections from 3 subjects (\#88035, \#93005, \#93047). For the present study, we decided to use the first antisense probe and its sense counterpart. The latter was prepared by linearization of the plasmid with XhoI and transcription with T3 RNA polymerase in the presence of $\left[{ }^{35} \mathrm{~S}\right] \mathrm{CTP}$.

\subsection{Specificity of TRH cRNA antisense probes}

The probes were checked for interfering homologies with other known sequences using BLAST [2], but none were found in databases at the National Center for Biotechnology Information, National Library of Medicine, USA. In addition, the human TRH cRNA sense probes were used as controls. Furthermore, the displacement of the $\left[{ }^{35} \mathrm{~S}\right] \mathrm{CTP}$ labeled antisense TRH probes by $5-, 10-, 50-$ or 100-fold excess of unlabeled TRH antisense probes was studied.

\subsection{Section treatment and in situ hybridization}

For in situ hybridization, sections were mounted with sterile water on $2 \%$ aminoalkylsilane (Sigma)-coated slides and dried at $38^{\circ} \mathrm{C}$. The sections were deparaffinized in xylene and brought to phosphate-buffered saline (PBS; $\mathrm{pH}$ 7) via a descending series of ethanols. The sections were treated with $0.2 \mathrm{~N}$ hydrochloric acid for $20 \mathrm{~min}$ and, after two washes in PBS of $5 \mathrm{~min}$ each, deproteinated with Proteinase K (Sigma) (10 $\left.\mu \mathrm{g} / \mathrm{ml}, 37^{\circ} \mathrm{C}, 30 \mathrm{~min}\right)$ [14]. The protease treatment was stopped by a rinse in glycine buffer ( $2 \mathrm{mg} / \mathrm{ml}$ PBS) followed by two rinses in PBS. Subsequently, the sections were dehydrated in an ascending ethanol series, delipidated with chloroform for $5 \mathrm{~min}$, dipped in $100 \%$ ethanol and dried in a vacuum desiccator.

The probes were diluted in hybridization buffer (HBF) (0.5 M sodium chloride, $1 \times$ Denhardt's solution, $10 \mathrm{mM}$ Tris, $\mathrm{pH}$ 7.6, $1 \mathrm{mM}$ (ethylenedinitrilo)tetraacetic acid (EDTA), $10 \%$ dextran sulfate, $0.5 \mathrm{mg} / \mathrm{ml}$ yeast tRNA, $50 \%$ formamide, $200 \mathrm{mM}$ dithiothreitol). Seventy $\mu \mathrm{l}$ of HBF containing about $8 \times 10^{5} \mathrm{dpm}$ of ${ }^{35} \mathrm{~S}$-labeled TRH probe were applied to the sections that subsequently were coverslipped and hybridized overnight in a humidified stove at $66^{\circ} \mathrm{C}$. The following day the coverslips were gently removed in $2 \times$ standard saline citrate (SSC; $1 \times$

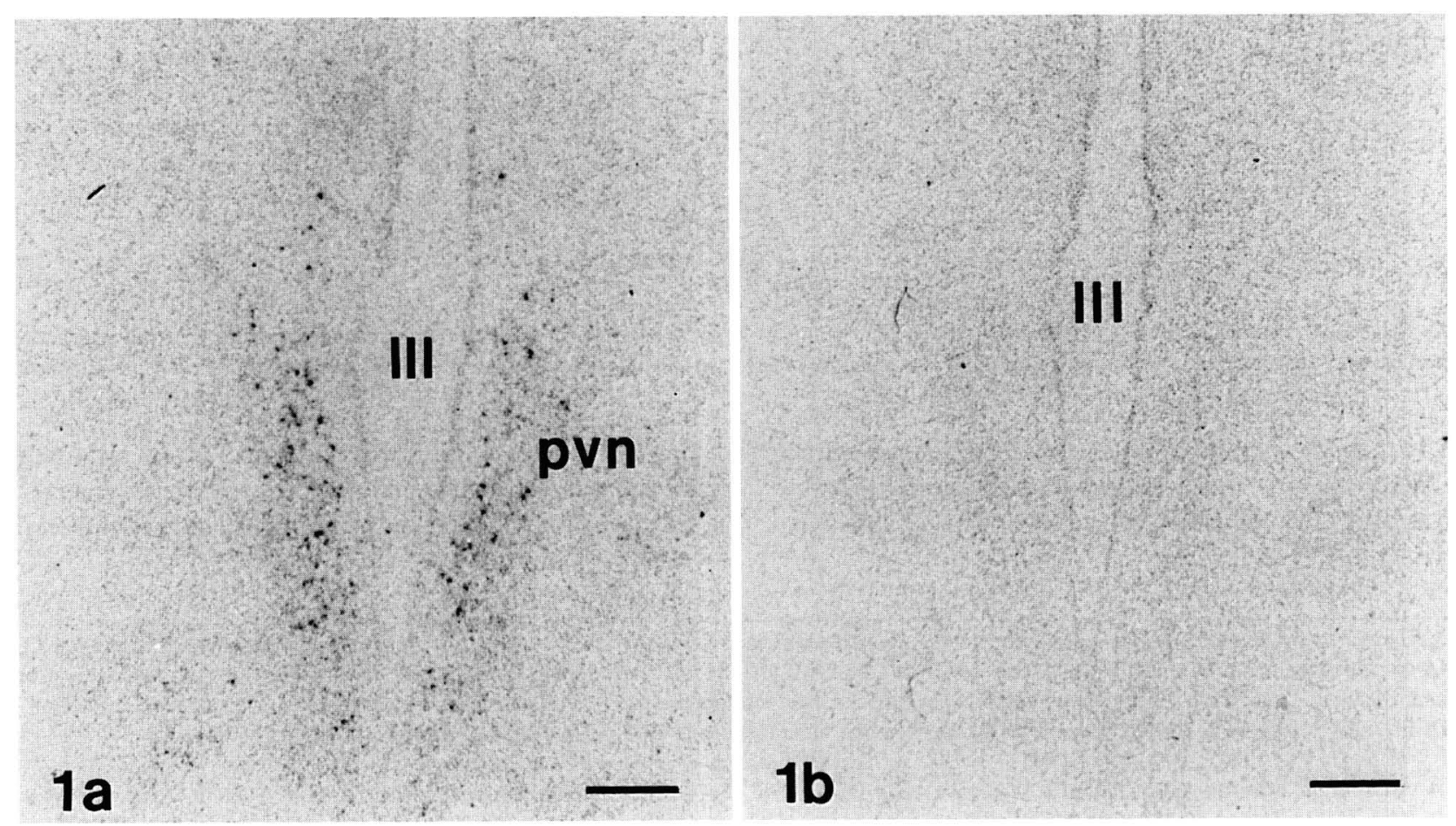

Fig. 1. Film autoradiograms of adjacent sections of the paraventricular nucleus (pvn) of the hypothalamus of subject \#88035. a: numerous neurons in a region adjoining the wall of the third ventricle (III) were detected after hybridization with the thyrotropin-releasing hormone (TRH) cRNA antisense probe. b: application of the TRH cRNA sense probe yielded no specific labeling. Scale bar $=1 \mathrm{~mm}$. 
A.

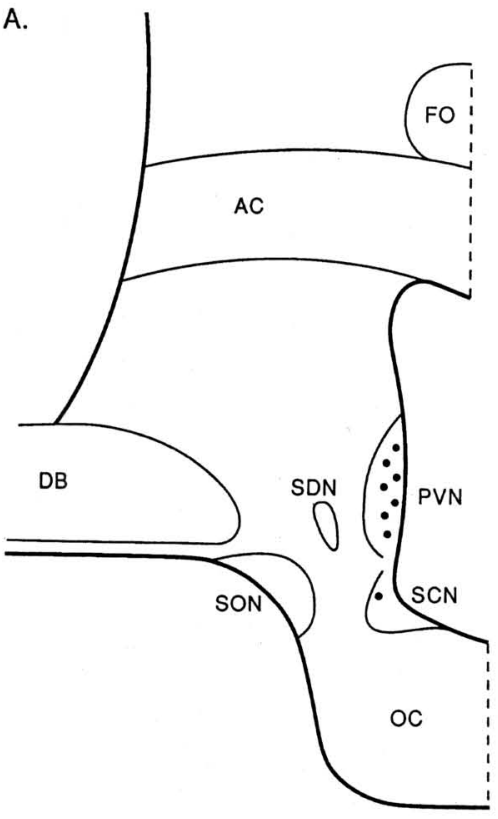

D.

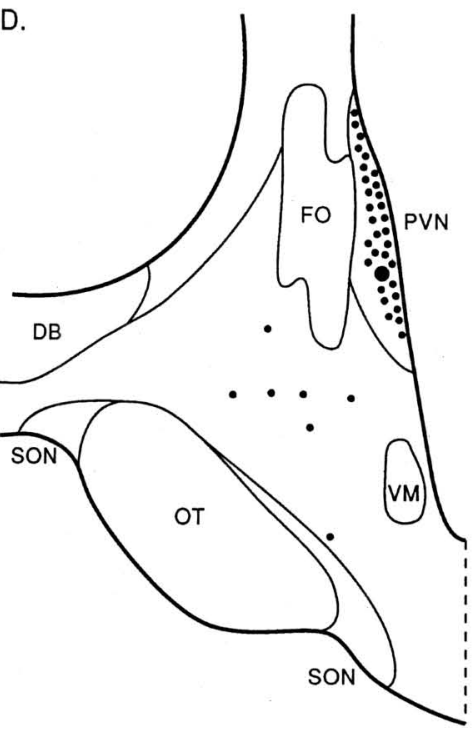

B.
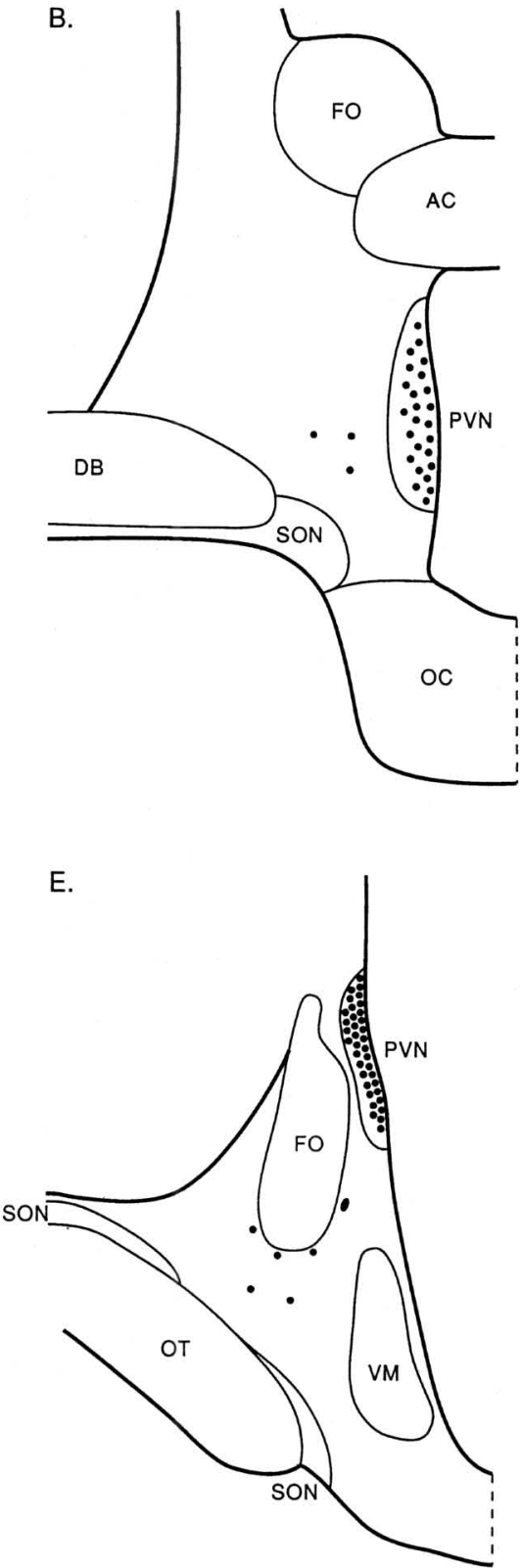

C.
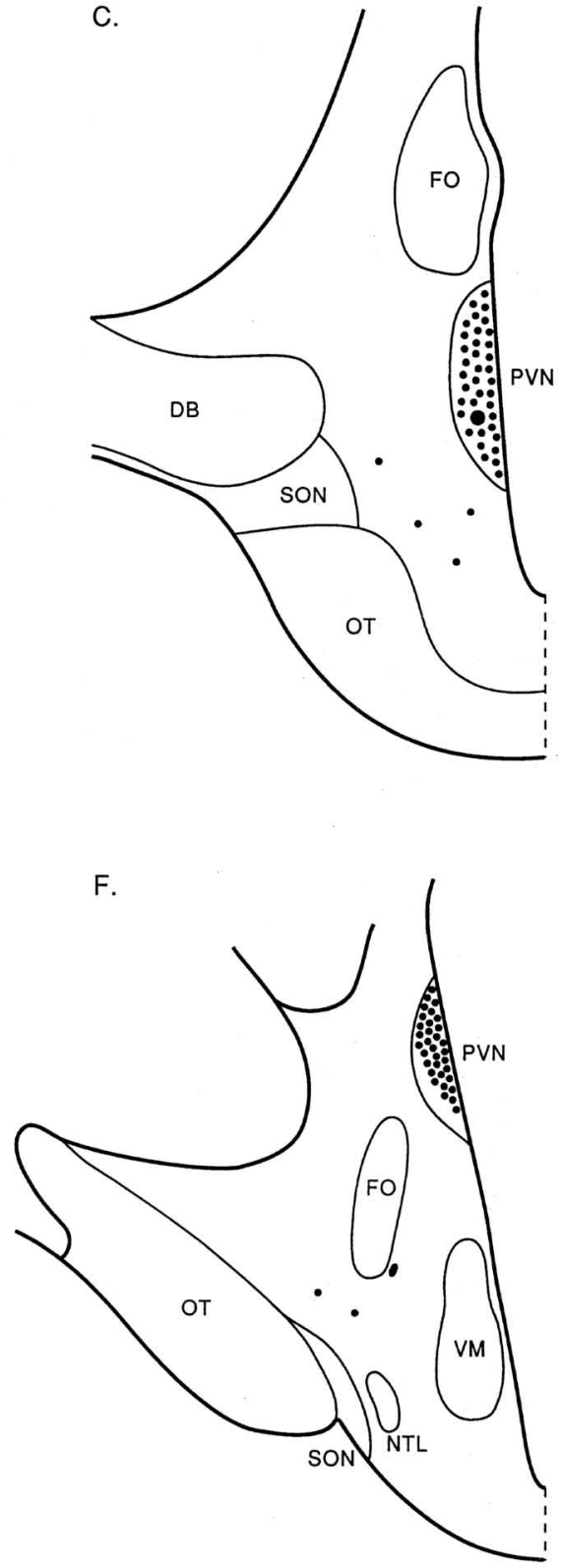

Fig. 2. Schematic illustrations (A-F) of coronal sections of the human hypothalamus at intervals of $800 \mu \mathrm{m}$ indicating the general distribution of thyrotropin-releasing hormone mRNA-containing cells. The presence of large or spindle shaped cells is indicated by a large or oval dot, respectively.

SSC is $0.15 \mathrm{M}$ sodium chloride, $0.015 \mathrm{M}$ sodium citrate, $\mathrm{pH} 7)$ and the sections were washed sequentially for 45 min at $60^{\circ} \mathrm{C}$ in $1 \times \mathrm{SSC}, 0.1 \times \mathrm{SSC}, 0.01 \times \mathrm{SSC}$ and finally in $0.001 \times \mathrm{SSC}$ for $3 \mathrm{~h}$ at $60^{\circ} \mathrm{C}$. In pilot experiments, RNase A (Sigma) treatment did not change the signal or the signal to noise ratio and we, therefore,

Fig. 3. Thionin-counterstained emulsion autoradiograms of the paraventricular nucleus (PVN) of subject \#93112. a: thyrotropin-releasing hormone (TRH) mRNA-containing cells (arrowheads) were covered by silver grains, while TRH mRNA-negative, mostly large, Nissl-rich neurons (arrows) were revealed by thionin staining. Scale bar $=70 \mu \mathrm{m}$. b, c: dark brown or black silver deposits that were resolved at high magnification evidenced the presence of TRH mRNA in small (b) and medium-sized PVN neurons (c). Note the thionin-stained, TRH mRNA-negative cell in c. Scale bar $=10 \mu \mathrm{m}$.

Fig. 4. Thyrotropin-releasing hormone mRNA-positive cells (arrows) in the anterior hypothalamic region of subject \#93049. Note the unlabeled thionin-stained cells. Scale bar $=40 \mu \mathrm{m}$.

Fig. 5. A thyrotropin-releasing hormone mRNA-containing spindle shaped cell in the perifornical area of the hypothalamus of subject \#93049. Note the adjacent unlabeled cell. Scale bar $=20 \mu \mathrm{m}$. 


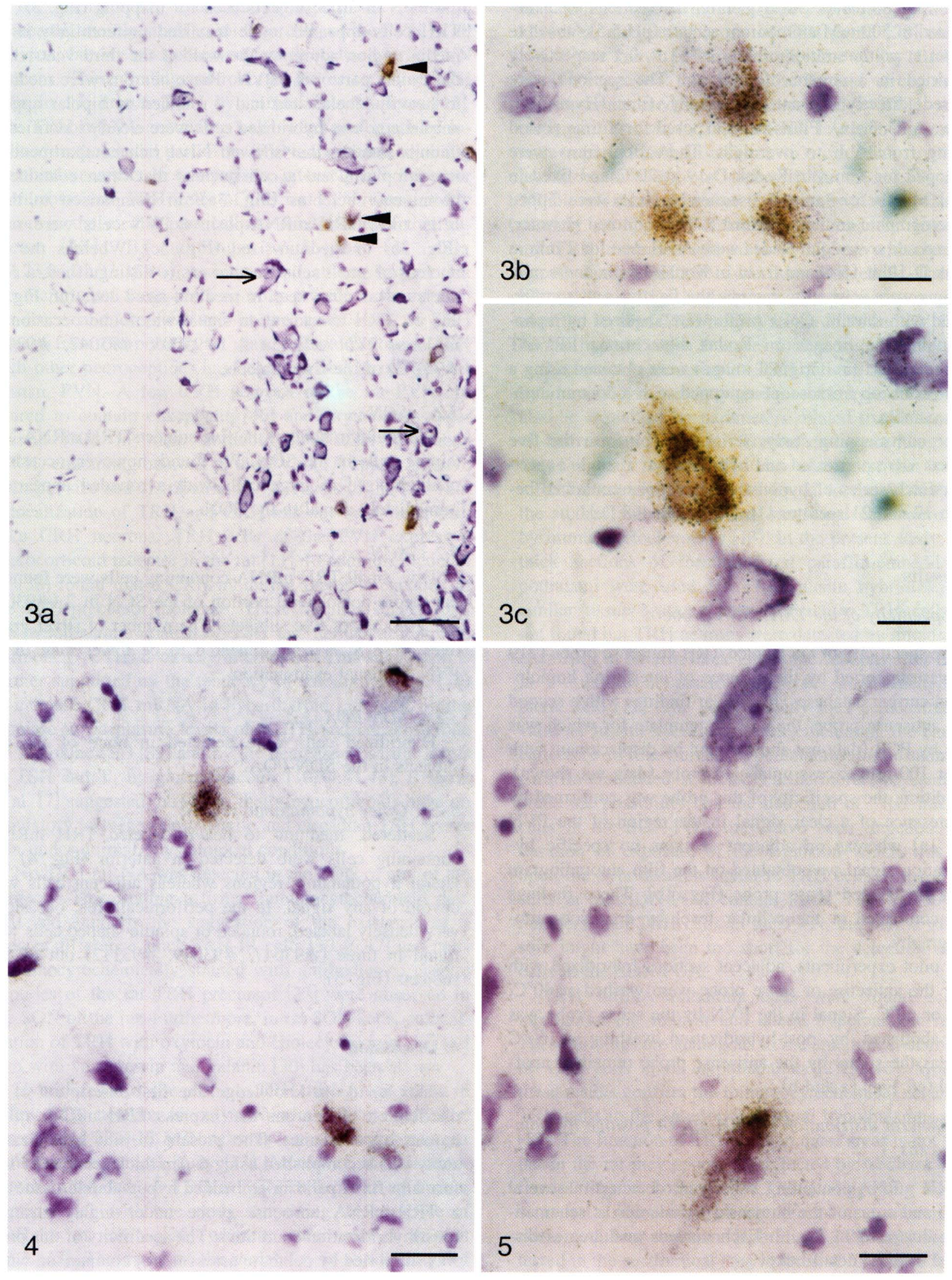


omitted this step from our protocol. In addition, the influence of the temperature of posthybridization washes by washing the sections of pilot experiments at $40^{\circ} \mathrm{C}, 50^{\circ} \mathrm{C}$ or $60^{\circ} \mathrm{C}$ was compared. Subsequently, the sections were dehydrated in $300 \mathrm{mM}$ ammonium acetate ( $\mathrm{pH}$ 5.5)/absolute ethanol at volume ratios of $1: 1,3: 7,1: 9,0: 1$ respectively and dried in a stream of cool air. The sections were apposed directly to autoradiography film (Hyperfilm$\beta$ max, Amersham). Films were exposed for a time period ranging from $5 \mathrm{~h}$ to overnight. Thereafter, films were developed for $4 \mathrm{~min}$ in Kodak D-19 at $20^{\circ} \mathrm{C}$ and fixed in Kodak Maxfix for $8 \mathrm{~min}$. Subsequently, slides were dipped in photographic emulsion (Ilford K.5; 1:1 diluted in water) and exposed overnight. Slides were developed for $2 \mathrm{~min}$ in Kodak D- 19 at $15^{\circ} \mathrm{C}$ and fixed in Kodak Unifix for $4 \mathrm{~min}$. Sections were washed to remove the fixative and counterstained with thionin. Color prints were acquired by rephotographing the images on Kodak Ektachrome EPY64T color reversal film. Original images were obtained using a Zeiss Axioskop microscope equipped with a $35 \mathrm{~mm}$ automatic camera.

For our mapping study, serial sections from the five subjects were pretreated and hybridized in a single experiment. Each series of hypothalamic sections contained between 12 and 21 sections ( $16 \pm 4$; mean \pm S.D.).

\section{Results}

\subsection{Specificity of the TRH cRNA probe}

The specificity of the labeled TRH antisense probe (219 bp) was supported by the absence of interfering homologies in current databases, by similar findings with a second TRH antisense probe, the $182 \mathrm{bp}$ template for which was made by PCR (data not shown), and by displacement with 50 - or 100-fold excess unlabeled probe (data not shown). In addition, the specificity of this probe was confirmed by the presence of a clear signal in the region of the PVN (Fig. 1a) whereas on adjacent sections no specific hybridization signal was obtained on the film autoradiogram using the labeled sense probe (Fig. 1b). These findings were confirmed at the cellular level by emulsion autoradiography.

In pilot experiments, adjacent sections hybridized with either the antisense or sense probe were washed at $40^{\circ} \mathrm{C}$, $50^{\circ} \mathrm{C}$ or $60^{\circ} \mathrm{C}$. Signal in the PVN by the sense probe was only abolished by post-hybridization washing at $60^{\circ} \mathrm{C}$ whereas the signal by the antisense probe remained unaffected (cf. Fig. 1a and b).

\subsection{General distribution of TRH $m R N A$ positive hypotha- lamic cells}

TRH mRNA-containing cells were detected in several nuclei and areas of the human hypothalamus as schematically illustrated in Fig. 2. Each nucleus and area is discussed in more detail below.

\subsubsection{PVN}

Numerous TRH mRNA-containing neurons were identified by the presence of dark brown or black silver grains in the PVN of all 5 subjects used for mapping (Fig. 3). The TRH cells appeared to be localized preferentially in the medial region adjoining the wall of the third ventricle in the caudal part of the PVN. These neurons were mediumto heavily-labeled and had a rounded to bipolar appearance. Large non-hybridized cells were clearly identified by thionin staining that showed Nissl rich compartments in the cytoplasm and a cell nucleus that often contained a prominent nucleolus (Fig. 3a). In comparison to these cells, most TRH mRNA-positive PVN cells were small (Fig. 3b) to medium-sized (Fig. 3c). Whereas the cell nucleus of small cells was not easily distinguished, a clear nucleus was often seen in medium-sized cells (cf. Fig. 3b and c). TRH hybridization signal was found occasionally in large PVN cells in 4 (\#93005, \#93047, \#93049, \#93103) of the five subjects.

\subsubsection{SON}

We found in none of the five subjects TRH mRNA-containing cells in the SON. We found, however, occasional medium-sized to large cells with a rounded appearance immediately dorsal to the SON.

\subsubsection{SCN}

Few, small TRH mRNA-containing cells were found in the medio-dorsolateral portion of the SCN in 2 (\#93049, \#93103) out of five subjects. The number of silver grains over these SCN cells appeared to be lower than in the PVN on visual examination.

\subsection{4. $S D N-P O A$}

Hybridized cells were detected in none of the five subjects in the SDN-POA.

\subsubsection{Other hypothalamic regions}

Scattered, medium- to heavily-labeled TRH mRNAcontaining cells were detected in anterior (Fig. 4) and lateral hypothalamic regions whereas adjacent cells were devoid of any signal. In the perifornical area, occasional very densely labeled, rounded or spindle-shaped cells were found in three (\#93047, \#93049, \#93112) out of five subjects (Fig. 5).

\section{Discussion}

This is, to our knowledge, the first description of the distribution of neurons that express TRH mRNA in the human hypothalamus. The present in situ hybridization study was accomplished using 6- $\mu \mathrm{m}$ thick sections of $10 \%$ formalin-fixed paraffin-embedded hypothalamic tissue and a TRH cRNA antisense probe under highly stringent (post)hybridization conditions. The specificity of this probe was supported by database assessments, comparison with a 
second TRH cRNA probe, displacement studies and comparison of signal obtained with a sense probe in adjacent tissue sections.

An intense TRH hybridization signal was found in numerous, mainly small to midsize cells of the PVN in all subjects, but we also observed few hybridized large PVN neurons. These findings corroborate the detection of TRH cells in the human PVN by immunocytochemistry [13]. The TRH mRNA-containing cells were preferentially localized in the caudal part of the PVN in a region adjoining the third ventricle. In comparison, intensely hybridized or immunostained TRH cells of the rat PVN were mostly found in the medial parvicellular subdivision of this nucleus [27]. By analogy with the rat data $[12,23,24,27,33,35,40]$, it seems reasonable to suggest that the majority of these PVN neurons project to the median eminence and are involved in the modulation of TSH release from the pituitary in man. Colocalization of TRH with other neuropeptides has been reported in rat, but not human, PVN. A few TRH neurons of the rat PVN appeared to contain enkephalin [46] and oxytocin or vasopressin [30]. In man, corticotropin-releasing hormone (CRH)-containing neurons in the PVN [37] appear to have a similar size and distribution as TRH cells of the PVN but colocalization of TRH and CRH has not been described. Like CRH neurons, TRH cells of the PVN express a glucocorticoid receptor in the rat [11]. In addition, Redei et al. [38] found that a CRH-inhibiting factor is encoded in the TRH precursor molecule. These findings suggest that the hypothalamic control of TSH and adrenocorticotropic hormone (ACTH) is closely intertwined. This suggestion is further supported by the tendency of triiodothyronine $\left(\mathrm{T}_{3}\right)$ to increase CRH mRNA in hyperthyroid rats [41], by the increase in rat plasma levels of ACTH and corticosterone by thyroxine $\left(\mathrm{T}_{4}\right)$ [39] and by the decrease of serum levels of TSH and $\mathrm{T}_{3}$ by glucocorticoids $[10,34,41,43]$. Brabant et al. [7] suggested, however, that glucocorticoids have no regulatory influence on pulsatile and circadian TSH secretion under normal physiological conditions.

No TRH mRNA was detected in the SON of any of the subjects. This finding affirms immunocytochemical data [13] and supports the suggestion of the existence of a species difference since TRH-IR cells $[30,46,47]$ and cells immunocytochemically stained with antibodies to cryptic peptides of the rat TRH precursor [27] were observed in the SON of the rat. Furthermore, in rat SON cells, colocalization of TRH with oxytocin and cholecystokinin [47] and also with vasopressin and galanin [30] has been shown.

Hybridization of the probe to TRH mRNA was found in a few SCN neurons in only two of the five cases. The detection of TRH-IR SCN neurons was also variable in our immunocytochemical study [13]. Moreover, the immunocytochemical data on TRH in SCN cells of the rat appear controversial, with one study supporting the presence of TRH in the SCN [26] whereas other studies do not $[23,32,47]$. The cause of the variability in the findings of
TRH neurons in the SCN remains unresolved but a potential factor is the circadian and circannual rhythmicity of this nucleus. We have not found any data in the literature concerning rhythms in TRH gene expression in the SCN. However, circulating levels of TSH in rat [28] and man $[48,49]$ are known to vary with the time of day. Brabant et al. [8] suggested that the pulsatile and circadian TSH secretions are predominantly controlled by TRH, and circadian differences in TRH mRNA levels in the rat PVN were reported [54]. In addition to a circadian rhythm and analogous to data from studies in the rat $[18,52]$, human TSH levels showed marked circannual variation [42]. Interestingly, an apparent circannual rhythm in rat hypothalamic TRH levels that seemed to be in phase with changes in hypothalamic CRH levels was demonstrated [3]. The possibility that circadian and circannual rhythmicity may influence the level of TRH mRNA in the SCN and PVN of the human hypothalamus deserves further study.

The variable detection of TRH cells in the human SCN by immunocytochemistry and in situ hybridization may also be explained by parameters related to the sensitivity of both techniques, e.g., fixation and embedding of the tissue. In this respect, it is also of interest that no TRH mRNA-containing cells were found in the SDN-POA of the studied subjects whereas occasional cells were found by immunocytochemistry [13]. In the present study, $6-\mu \mathrm{m}$ thick sections of formalin-fixed paraffin-embedded hypothalami were used for TRH in situ hybridization. In similar tissue sections, immunoreactive TRH cells were not found but TRH neurons were detected by immunocytochemistry in $50 \mu \mathrm{m}$ thick vibratome sections after fixation in a mixture of paraformaldehyde, glutaraldehyde and picric acid [13]. The present study thus demonstrates the value of in situ hybridization for elucidating the chemoarchitecture of the human hypothalamus in formalin-fixed paraffin-embedded sections. Furthermore, we cannot exclude the possibility that the detection of TRH mRNA in cells in the SDN-POA may have been impeded by the duration of exposure of the emulsion which was based upon the hybridization signal in TRH cells of the PVN. If cells in the SDN-POA contain lower TRH mRNA copy numbers than TRH cells in the PVN, the period of exposure might have been too short for the detection of TRH cells in the SDN-POA.

TRH mRNA-containing cells were found scattered throughout the anterior and lateral hypothalamic regions. These findings are analogous to the anatomical distribution of TRH cells in rat hypothalamus $[27,32,46]$. Moreover, these results confirm the immunocytochemical detection of TRH cells in the anterior and lateral hypothalamus in man [13]. The function of TRH cells in these areas is not known but in the rat they appear not affected by feedback regulation of thyroid hormone [24,27,40], suggesting that they serve not a neuroendocrine but rather a neurotransmitter or neuromodulator function. Hybridized TRH cells were detected in the perifornical area in three of five cases whereas 
no TRH cells were detected in the human perifornical area by immunocytochemistry [13]. The reason for this discrepancy is not resolved but it might be that the spindle-shaped neurons (cf. Fig. 5) were obscured in the immunocytochemical study by the density of the staining and the fiber networks due to the use of $50-\mu \mathrm{m}$ thick vibratome sections. The presence of TRH cells in the perifornical region is consistent with studies in rat $[23,31,32,47]$. TRH cells of the rat perifornical nucleus project to the lateral septum and appear to synthesize enkephalin [31,47]. Hypothalamic TRH gene expression seems to be cell-specific. In the PVN, but not in other hypothalamic nuclei, TRH mRNA levels were affected by feedback regulation of thyroid hormone in rat $[12,19,24,27,40]$. In addition, Blake et al. [4] found that the reduction in circulating $\mathrm{T}_{3}$ after 48 -h food deprivation was associated with both decreased TRH mRNA in the PVN and significantly declined TRH levels in portal blood. Furthermore, TRH mRNA in the PVN of the rat appeared to be modulated by additional factors such as interleukin-1 $\beta$ [20], cold exposure [54], light cycle [54] and glucocorticoids $[21,29,50]$. The small number of subjects in the present study did not allow a systematic quantitative examination of these or other variables that might have affected TRH gene expression in the hypothalamus, e.g. the patient's illnesses or medication.

TRH gene expression in the PVN or, indeed, in the hypothalamus had not been shown before in man. The present in situ hybridization study shows TRH mRNAcontaining neurons in the human hypothalamus and in the PVN in particular. We will proceed with quantitative in situ hybridization studies of TRH mRNA in the PVN of subjects whose ante-mortem thyroidal status was assessed to determine the role of TRH gene expression in PVN neurons in various pathologies such as thyroidal disorders and nonthyroidal illness in man.

\section{Acknowledgements}

We thank Mr. B. Fisser for sectioning and immunocytochemical staining of the tissues for vasopressin, Ms. U. Unmehopa for technical assistance and, Mr. H. Stoffels and Mr. G. van der Meulen for the illustrations. We are indebted to all the employees of the Netherlands Brain Bank, Amsterdam, (coordinator Dr. R. Ravid) for their help in obtaining human brain tissue. This work was supported by the Innovation Fund of the Royal Dutch Academy of Sciences (S.E.F.G.) and the Dr. Lugardine Bouwman Stichting (E.F.).

\section{References}

[1] Allen, L.S., Hines, M., Shryne, J.E. and Gorski, R.A., Two sexually dimorphic cell groups in the human brain, J. Neurosci., 9 (1989) 497-506.
[2] Altschul, S.F., Gish, W., Miller, W., Meyers, E.W. and Lipman, D.J., Basic local alignment search tool, J. Mol. Biol., 215 (1990) 403-410.

[3] Bisette, G., Griff, D., Carnes, M., Goodman, B., Lavine, M. and Levant, B., Apparent seasonal rhythms in hypothalamic neuropeptides in rats without photoperiod changes, Endocrinology, 136 (1995) $622-628$

[4] Blake, N.G., Eckland, D.J.A., Foster, O.J.F. and Lightman, S.L., Inhibition of hypothalamic thyrotropin-releasing hormone messenger ribonucleic acid during food deprivation, Endocrinology, 129 (1991) 2714-2718.

[5] Borson-Chazot, F., Jordan, J., Fevre-Montange, M., Kopp, N., Tourniaire, J., Rouzioux, J.M., Veisseire, M. and Mornex, R., TRH and LH-RH distribution in discrete nuclei of the human hypothalamus: evidence for a left prominence of TRH, Brain Res., 382 (1986) 433-436.

[6] Braak, H. and Braak, E., Anatomy of the human hypothalamus (chiasmatic and tuberal region). In D.F. Swaab, M.A. Hofman, M. Mirmiran, R. Ravid and F.W. van Leeuwen (Eds.), The Human Hypothalamus in Health and Disease, Progress in Brain Research, Vol. 93, Elsevier, Amsterdam, 1992, pp. 3-16.

[7] Brabant, A., Brabant, G., Schuermeyer, T., Ranft, U., Schmidt, F.W., Hesch, R.D. and von zur Mühlen, A., The role of glucocorticoids in the regulation of thyrotropin, Acta Endocrinol., 121 (1989) 95-100.

[8] Brabant, G., Prank, K., Hoang-Vu, C., Hesch, R.D. and von zur Mühlen, A., Hypothalamic regulation of pulsatile thyrotropin secretion, J. Clin. Endocrinol. Metab., 72 (1991) 145-150.

[9] Brownstein, M.J., Palkovits, M., Saavedra, J.M., Bassiri, R.M. and Utiger, R.D., Thyrotropin-releasing hormone in specific nuclei of rat brain, Science, 185 (1974) 267-269.

[10] Burr, W.A., Ramsden, D.B., Griffiths, R.S., Black, E.G., Hoffenberg, R., Meinhold, H. and Wenzel, K.W., Effect of a single dose of dexamethasone on serum concentrations of thyroid hormones, Lancet, 2 (7976) (1976) 58-61.

[11] Cintra, A., Fuxa, K., Wikström, A.C., Visser, T. and Gustafsson, J.A., Evidence for thyrotropin-releasing hormone and glucocorticoid-receptor immunoreactive neurons in various preoptic and hypothalamic nuclei of the male rat, Brain Res., 506 (1990) 139-144.

[12] Dyess, E.M., Segerson, T.P., Lipositz, Z., Paull, W.K., Kaplan, M.M., Wu, P., Jackson, I.V.M. and Lechan, R.M., Triiodothyronine exerts direct cell-specific regulation of thyrotropin-releasing hormone gene expression in the hypothalamic paraventricular nucleus, Endocrinology, 123 (1988) 2291-2297.

[13] Fliers, E., Noppen, N.W.A.M., Wiersinga, W.M., Visser, T.J. and Swaab, D.F., Distribution of thyrotropin releasing hormone (TRH) containing cells and fibers in the human hypothalamus, J. Comp. Neurol., 350 (1994) 311-323.

[14] Guldenaar, S.E.F. and Swaab, D.F., Estimation of oxytocin mRNA in the human paraventricular nucleus in AIDS by means of quantitative in situ hybridization, Brain Res., 700 (1995) 107-114.

[15] Hökfelt, T., Fuxe, K., Johansson, O., Jeffcoate, S. and White, N., Distribution of thyrotropin-releasing hormone in the central nervous system as revealed with immunohistochemistry, Eur. J. Pharmacol., 34 (1975) 389-392.

[16] Jackson, I.M.D. and Reichlin, S., Thyrotropin-releasing hormone (TRH): Distribution in hypothalamic and extrahypothalamic brain tissues of mammalian and submammalian chordates, Endocrinology, 95 (1974) 854-862.

[17] Jackson, I.M.D., Adelman, L.S., Munsat, T.L., Forte, S. and Lechan, R.M., Amyotrophic lateral sclerosis: Thyrotropin-releasing hormone and histidyl proline diketopiperazine in the spinal cord and cerebrospinal fluid, Neurology, 36 (1986) 1218-1223.

[18] Jordan, D., Perrin, F. and Mornex, R., Circannual variations of TSH circadian rhythm parameters in the rat, Neuroendocrinology, 36 (1983) 17-20.

[19] Kakucska, I., Rand, W. and Lechan, R.M., Thyrotropin-releasing 
hormone gene expression in the hypothalamic paraventricular nucleus is dependent upon feedback regulation by both triiodothyronine and thyroxine, Endocrinology, 130 (1992) 2845-2850.

[20] Kakucska, I., Romero, L.I., Clark, B.D., Rondeel, J.M.M., Qi, Y., Alex, S., Emerson, C.H. and Lechan, R.M., Suppression of thyrotropin releasing hormone gene expression by interleukin- $1 \beta$ in the rat: Implications for nonthyroidal illness, Neuroendocrinology, 59 (1994) 129-137.

[21] Kakucska, I., Qi, Y. and Lechan, R.M., Changes in adrenal status affect hypothalamic thyrotropin-releasing hormone gene expression in parallel with corticotropin-releasing hormone, Endocrinology, 136 (1995) 2795-2802.

[22] Kardon, F.C., Winokur, A. and Utiger, R.D., Thyrotropin-releasing hormone (TRH) in the rat spinal cord, Brain Res., 122 (1977) 578-581.

[23] Kawano, H., Tsuruo, Y., Bando, H. and Daikoku, S., Hypophysiotropic TRH-producing neurons identified by combining immunohistochemistry for pro-TRH and retrograde tracing, J. Comp. Neurol., 307 (1991) 531-538.

[24] Koller, K.J., Wolff, R.S., Warden, M.K. and Zoeller, R.T., Thyroid hormones regulate levels of thyrotropin releasing hormone mRNA in the paraventricular nucleus, Proc. Natl. Acad. Sci. USA, 84 (1987) $7329-7333$

[25] Kubek, M., Wilber, J.F. and George, J.M., The distribution and concentration of thyrotropin-releasing hormone in discrete human hypothalamic nuclei, Endocrinology, 105 (1979) 537-540.

[26] Lechan, R.M. and Jackson, I.M.D., Immunohistochemical localization of thyrotropin-releasing hormone in the rat hypothalamus and pituitary, Endocrinology, 111 (1982) 1210-1216.

[27] Lechan, R.M. and Segerson, T.P., Pro-TRH gene expression and precursor peptides in rat brain: Observations by hybridization analysis and immunocytochemistry, Ann. NY Acad. Sci., 553 (1989) 29-59.

[28] Leppäluoto, J., Ranta, T. and Tuomisto, J., Diurnal variation of serum immunoassayable thyrotropin (TSH) concentration in the rat, Acta Physiol. Scand., 90 (1974) 699-702.

[29] Luo, L.-G., Bruhn, T.O. and Jackson, I.M.D., Glucocorticoids stimulate thyrotropin-releasing hormone gene expression in cultured hypothalamic neurons, Endocrinology, 136 (1995) 4945-4950.

[30] Meister, B., Villar, M.J., Ceccatelli, S. and Hökfelt, T., Localization of chemical messengers in magnocellular neurons of the hypothalamic supraoptic and paraventricular nuclei: An immunohistochemical study using experimental manipulation, Neuroscience, 37 (1990) 603-633.

[31] Merchenthaler, I., Co-localization of enkephalin and TRH in perifornical neurons of the rat hypothalamus that project to the lateral septum, Brain Res., 544 (1991) 177-180.

[32] Merchenthaler, I., Csernus, V., Csontos, C., Petrusz, P. and Mess, B., New data on the immunocytochemical localization of thyrotropin-releasing hormone in the rat central nervous system, Am. J. Anat., 181 (1988) 359-376.

[33] Merchenthaler, I. and Liposits, Z., Mapping of thyrotropin-releasing hormone (TRH) neuronal systems of rat forebrain projecting to the median eminence and the OVLT. Immunocytochemistry combined with retrograde labeling at the light and electron microscopic levels, Acta Biol. Hung., 45 (1994) 361-374.

[34] Nicoloff, J.T., Fisher, D.A. and Appleman Jr., M.D., The role of glucocorticoids in the regulation of thyroid function in man, J. Clin. Invest., 49 (1970) 1922-1929.

[35] Nishiyama, T., Kawano, H., Tsuruo, Y., Maegawa, M., Hisano, S., Adachi, T., Daikoku, S. and Suzuki, M., Hypothalamic thyrotropin releasing hormone (TRH) containing neurons involved in the hypothalamic hypophysial thyroid axis. Light microscopic immunohistochemistry, Brain Res., 345 (1985) 205-218.

[36] Okon, E. and Koch, Y., Localisation of gonadotropin-releasing and thyrotropin-releasing hormones in human brain by radioimmunoassay, Nature, 263 (1976) 345-347.

[37] Raadsheer, F.C., Sluiter, A.A., Ravid, R., Tilders, F.J.H. and Swaab, D.F., Localization of corticotropin-releasing hormone (CRH) neurons in the paraventricular nucleus of the human hypothalamus: age-dependent colocalization with vasopressin, Brain Res., 615 (1993) 50-62.

[38] Redei, E., Hilderbrand, H. and Aird, F., Corticotropin release-inhibiting factor is preprothyrotropin-releasing hormone-(178-199), Endocrinology, 136 (1995) 3557-3563.

[39] Sanchez-Franco, F., Fernandez, L., Fernandez, G. and Cacicedo, L., Thyroid hormone action on ACTH secretion, Horm. Metab. Res., 21 (1989) $550-552$.

[40] Segerson, T.P., Kauer, J., Wolfe, H.C., Mobtaker, H., Wu, P., Jackson, I.M.D. and Lechan, R.M., Thyroid hormone regulates TRH biosynthesis in the paraventricular nucleus of the rat hypothalamus, Science, 238 (1987) 78-80.

[41] Shi, Z.X., Levy, A. and Lightman, S.L., Thyroid hormone-mediated regulation of corticotropin-releasing hormone messenger ribonucleic acid in the rat, Endocrinology, 134 (1994) 1577-1580.

[42] Simoni, M., Velardo, A., Montanini, V., Faustini Fustini, M., Seghedoni, S. and Marrama, P., Circannual rhythm of plasma thyrotropin in middle-aged and old euthyroid subjects, Horm. Res., 33 (1990) 184-189.

[43] Sowers, J.R., Carlson, H.E., Brautbar, N. and Hershman, J.M., Effect of dexamethasone on prolactin and TSH responses to TRH and metoclopramide in man, J. Clin. Endocrinol. Metab., 44 (1977) 237-241.

[44] Swaab, D.F. and Fliers, E., A sexually dimorphic nucleus in the human brain, Science, 228 (1985) 1112-1115.

[45] Swaab, D.F., Fliers, E. and Partiman, T.S., The suprachiasmatic nucleus of the human brain in relation to sex, age and senile dementia, Brain Res., 342 (1985) 37-44.

[46] Tsuruo, Y., Hökfelt, T. and Visser, T.J., Thyrotropin-releasing hormone (TRH)-immunoreactive cell groups in the rat central nervous system, Exp. Brain Res., 68 (1987) 213-217.

[47] Tsuruo, Y., Ceccatelli, S., Villar, M.J., Hökfelt, T., Visser, T.J., Terenius, L., Goldstein, M., Brown, J.C., Buchan, A., Walsh, J., Morris, M., Sofroniew, M.V. and Verhofstadt, A., Coexistence of TRH with other neuroactive substances in the rat central nervous system, J. Chem. Neuroanat., 1 (1988) 235-253.

[48] Van Coevorden, A., Mockel, J., Laurent, E., Kerkhofs, M., L'Hermite-Balériaux, M., Decoster, C., Nève, P. and Van Cauter, E., Neuroendocrine rhythms and sleep in aging men, Am. J. Physiol., 260 (1991) E651-661.

[49] Vanhaelst, L., Van Cauter, E., Degaute, J.P. and Golstein, J., Circadian variations of serum thyrotropin levels in man, J. Clin. Endocrinol. Metab., 35 (1972) 479-482.

[50] Wilber, J.F. and Utiger, R.D., The effect of glucocorticoids on thyrotropin secretion, J. Clin. Invest., 48 (1969) 2096-2103.

[51] Winokur, A. and Utiger, R.D., Thyrotropin-releasing hormone: Regional distribution in rat brain, Science, 185 (1974) 265-267.

[52] Wong, C., Döhler, K., Atkinson, M.J., Geerlings, H., Hesch, R. and von zur Mühlen, A., Influence of age, strain and season on diurnal periodicity of thyroid stimulating hormone, thyroxine, triiodothyronine and parathormone in the serum of male laboratory rats, Acta Endocrinol., 102 (1983) 377-385.

[53] Yamada, M., Radovick, S., Wondisford, F.E., Nakayama, Y., Weintraub, B.D. and Wilber, J.F., Cloning and structure of human genomic DNA and hypothalamic cDNA encoding human preprothyrotropin-releasing hormone, Mol. Endocrinol., 4 (1990) 551-556.

[54] Zoeller, R.T., Kabeer, N. and Albers, H.E., Cold exposure elevates cellular levels of messenger ribonucleic acid encoding thyrotropinreleasing hormone in the paraventricular nucleus despite elevated levels of thyroid hormones, Endocrinology, 127 (1990) 2955-2962. 